\section{Effectiveness of Readily Available Adhesive Tapes as Grafting Wraps}

Suman Singha

Division of Plant and Soil Sciences, West Viginia University,
Morgantown, WV 26506-6108

Additional index words. whip grafting, electrical tape, duct tape, grafting tape, masking tape, polyethylene strips, Malus domestics

"Nurseryman's grafting tape is an excellent material for tying the stock and scion together during grafting (Hartmann and Kester, 1983). Other materials that have been used include polyethylene strips (East Malling Research Station, 1962), parafilm (Beineke, 1978), and masking tape (Hartman and Kester, 1983). The objective of this study was to determine the effectiveness of readily available electrical and duct tape as grafting wraps, especially for use by amateur horticulturists.

Dormant scions of 'Golden Delicious' apple (Malus domestics Borkh.) were collected in early January and stored at 5C until used. 'Antonovka' seedling rootstock, obtained from a commercial source in February, were potted in 5.7-liter plastic pots and maintained in the greenhouse. Uniform, actively growing rootstock $\approx 7 \mathrm{~mm}$ in diameter were whip grafted on 11 Apr. 1988. Fifteen replicate grafts were each wrapped with grafting tape, masking tape, electrical tape, duct tape, or polyethylene strips. The grafting tape (Permacel, New Brunswick, N. J.) was ordered from the catalog of a horticultural supply company, while the other tapes were purchased at a local hardware store. Information on the dimensions and unit cost of these adhesive tapes is provided in Table 1 . The duct tape was cut in half and a $2.5-\mathrm{cm}$ width was used for grafting. Polyethylene strips were prepared by cutting clear poly-

Received for publication 26 July 1989. Approved for publication by the Director, West Virginia Agr. and For. Expt. Sta. as Scientific Article no. 2171. The cost of publishing this paper was defrayed in part by the payment of page charges. Under postal regulations, this paper therefore must be hereby marked advertisement solely to indicate this fact.

Calculated for $2.5-\mathrm{cm}$ width used for grafting. ethylene film into 2.5 -cm-wide ribbons. Grafted plants, arranged in a randomized complete-block design, were placed in a sheltered location outside the greenhouse. To prevent the wraps from constricting the growth of the union, vertical cuts were made through the wraps on opposite sides of each graft union on 23 May 1988. Also at this time, all but the single most vigorous shoot were removed from each scion. During the remainder of the growing season, any laterals arising from this shoot were removed. The plants were given uniform fertilizer, irrigation, and pesticide applications. Data were subjected to analysis of variance, and means separated using Duncan's multiple range test.

All the grafts were successful, indicating that none of the wraps had any deleterious effects on graft union formation. Shoot length measurements in June indicated that trees grafted using masking tape were significantly smaller than those wrapped with either duct tape or polyethylene strips (Table 1).
The difference in shoot length between the masking tape and polyethylene film treatments was maintained to the end of the growing season, whereas no differences existed between the remaining treatments. The reduced growth in trees grafted using masking tape may be attributed to the poor adhesion of this tape and its undesirable tendency to unravel, especially during the healing of the graft union. There was no significant influence of the wraps on the stem caliper (mean, $12 \mathrm{~mm}$ ) measured at the end of the growing season.

Although masking tape has the lowest unit cost, its tendency to unravel is a drawback. Polyethylene film is a readily available and effective grafting wrap (East Mailing Research Station, 1962; Larsen, 1976). Rolls of polyethylene tape can be obtained through the catalog of some hortictilural supply companies. However, the lack of adhesive may make polyethylene hard to use. The ease of usage, effectiveness, and ready availability make electrical tape and duct tape especially useful to amateur horticulturists.

\section{Literature Cited}

Beineke, W.J. 1978. Parafilm: A new way to wrap grafts. HortScience 13:284.

East Mailing Research Station. 1962. Experimental nurseries. Rpt. E. Mailing Res. Sta. 1961:5.

Hartmann, H.T. and D.E. Kester. 1983. Plant propagation-Principles and practices. 4th ed. Prentice Hall, New York.

Larsen, F.E. 1976. Budding and grafting with polyethylene strips. Plant Propagator 22(3):1011 .

Table 1. Comparison between grafting wraps and their influence on shoot length of 'Golden Delicious' apple trees whip grafted on 11 Apr. (all dates 1988).

\begin{tabular}{|c|c|c|c|c|}
\hline \multirow[b]{2}{*}{ Wrap } & \multirow{2}{*}{$\begin{array}{l}\text { Dimensions } \\
\text { of roll }\end{array}$} & \multirow{2}{*}{$\begin{array}{l}\text { Price } \\
(\mathrm{c} / \mathrm{m})\end{array}$} & \multicolumn{2}{|c|}{ Shoot length $(\mathrm{cm})$ ' } \\
\hline & & & 23 June & 30 Sept. \\
\hline $\begin{array}{l}\text { Grafting } \\
\text { tape }\end{array}$ & $\begin{array}{c}1.9 \mathrm{~cm} \times 55 \mathrm{~m} \\
(0.75 \mathrm{inch} \times 180 \mathrm{ft})\end{array}$ & 12.3 & $56.0 \mathrm{ab}$ & $119 \mathrm{ab}$ \\
\hline $\begin{array}{l}\text { Masking } \\
\text { tape }\end{array}$ & $\begin{array}{c}1.9 \mathrm{~cm} \times 55 \mathrm{~m} \\
(0.75 \mathrm{inch} \times 180 \mathrm{ft})\end{array}$ & 1.7 & $50.4 \mathrm{~b}$ & $116 \mathrm{~b}$ \\
\hline $\begin{array}{l}\text { Electrical } \\
\text { tape }\end{array}$ & $\begin{array}{r}1.9 \mathrm{~cm} \times 18 \mathrm{~m} \\
(0.75 \mathrm{inch} \times 60 \mathrm{ft})\end{array}$ & 4.2 & $51.7 \mathrm{ab}$ & $119 \mathrm{ab}$ \\
\hline Duct tape & $\begin{array}{c}5.0 \mathrm{~cm} \times 55 \mathrm{~m} \\
(2.0 \mathrm{inch} \times 180 \mathrm{ft})\end{array}$ & $5.4^{y}$ & $58.0 \mathrm{a}$ & $122 \mathrm{ab}$ \\
\hline $\begin{array}{l}\text { Polyethylene } \\
\text { strips }\end{array}$ & $\ldots$ & $\cdots$ & $57.1 \mathrm{a}$ & $125 \mathrm{a}$ \\
\hline
\end{tabular}

${ }^{2}$ Mean separation in columns by Duncan's multiple range test $(P=0.05)$. 